\title{
The Effect of Mergers and Acquisitions on Bank Performance in Ghana
}

\section{Alhassan Musah ${ }^{\rtimes}$ \\ Mohammed Abdulai ${ }^{2}$ Hilda Baffour ${ }^{3}$}

${ }^{t}$ School of Business, Dominion University College, Accra, Ghana

Email:alaye88@gmail.com

${ }^{2}$ Department of Distance Education, University of Ghana, Accra, Ghana.

${ }^{8}$ Krwame Nkrumah University of Science and Technology, Ghana.

\section{Abstract}

The study examined the consequence of mergers and acquisition on bank performance in Ghana. Specifically, the study investigated the effect of mergers and acquisition on net profit margin, return on assets and return on equity of commercial banks in Ghana. Data from the annual reports of eight (8) commercial banks over a 10-year period (2009-2018) were collected and analysed by the use of descriptive statistics, correlation analysis, and regression analysis. The findings revealed a negative and significant association between mergers and acquisition and net profit margin. There existed a positive but statistically insignificant relationship between mergers and acquisition and return on assets of commercial banks in Ghana. Further, there was a negative but statistically insignificant relationship between mergers and acquisition and return on equity. The results, however, could not establish a conclusive evidence of the impact of mergers and acquisition on bank performance, implying that mergers and acquisition might not necessarily improve bank financial performance.

Keywords: Merger and acquisition, Profit Margin, ROA, ROE, Performance, Banks.

JEL Classification: G21, G34.

Citation | Alhassan Musah; Mohammed Abdulai; Hilda Baffour (2020). The Effect of Mergers and Acquisitions on Bank Performance in Ghana. Asian Journal of Economics and Empirical Research, 7(1): 36-45.

History:

Received: 22 November 2019

Revised: 30 December 2019

Accepted: 3 February 2020

Published: 26 February 9090

Licensed: This work is licensed under a Creative Commons Attribution 3.0 License $($ (c) $)$ E

Publisher: Asian Online Journal Publishing Group
Acknowledgement: All authors contributed to the conception and design of the study.

Funding: This study received no specific financial support.

Funding: This study received no specific financial support.
Competing Interests: The authors declare that they have no conflict of interests.

Transparency: The authors confirm that the manuscript is an honest, accurate, and transparent account of the study was reported; that no vital features of the study have been omitted; and that any discrepancies from the study as planned have been explained.

Ethical: This study follows all ethical practices during writing.

\section{Contents}

1. Introduction

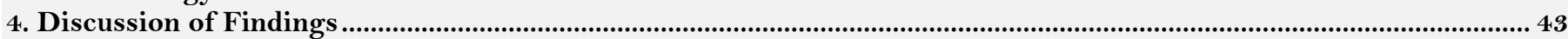

5. Conclusion

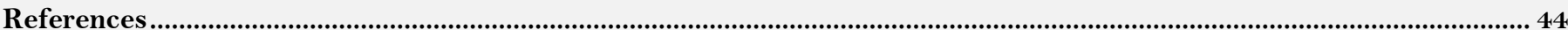




\section{Contribution of this paper to the literature}

The study extends previous studies on the effect of mergers and acquisition on financial performance which focused on smaller samples and case studies to using a sample of all commercial banks that have been involved in mergers and acquisition in the last 10 years. The results therefore represent a more comprehensive study on how mergers and acquisition affect financial performance of commercial banks in Ghana.

\section{Introduction}

Mergers and acquisition falls under inorganic or artificial growth which has attracted attention all over the world and across all sectors (Oduro and Agyei, 2013). The objective of most mergers and acquisition is to propel growth and ultimately maximize shareholders' growth (Maama et al., 2017; Mensah and Onumah, 2017). Several reasons have been given for corporations trying to grow using mergers and acquisition rather than through natural growth. It is estimated that as far as 2008 , the global mergers and acquisition market was worth $\$ 3.280$ billion, which was a reduction of $29 \%$ from the 2007 estimate (Amewu, 2014). The high numbers in global mergers and acquisitions have also resulted in several academic literatures on the subject matter in various countries and industries (Haleblian and Finkelstein, 1999). Saboo et al. (2017) argue that one of the biggest drivers of mergers and acquisition is the motivation to eliminate or reduce competition. It also helps to increase the size and operations of firms in order to enable them enjoy economies of scale, which could improve their performance in terms of profitability (Harvey, 2015). According to Harvey (2015) firms adopt mergers and acquisition as one of the most useful corporate strategies to help respond to changes in the business environment and globalization. Zaremba and Płotnicki (2016) see mergers and acquisition as part of corporate restructuring, which allows companies to re-establish or improve their competitive advantage in the industry. Aggarwal and Singh (2015) posits that corporate restructuring through mergers and acquisition is intended to skip some steps in the ladder of growth. One of the most profitable growth strategies a firm can adopt in today's competitive environment is through mergers and acquisitions (Cho et al., 2016). Companies also use mergers and acquisition as a risk management strategy, which helps the company to diversify risk and enhance its value (Agbloyor et al., 2012). Additionally, mergers and acquisition helps company to gain market power and become dominant players in the industry they operate (Amewu, 2014). Some studies even argue that synergies and tax benefits are also important considerations in corporate mergers and acquisitions (Harvey, 2015). Mergers and acquisition could also be a means to improve managerial skills or technological enhancement and innovation, improve liquidity and eliminate inefficiencies (Seidu, 2009). Companies especially multinational companies can use acquisition as a means to enter new market or diversify their operations (Harvey, 2015). In spite of the above, some researchers are of the view that mergers and acquisitions can bring negative consequences if the process is not properly managed (Altunbaş and Marqués-Ibanez, 2008; Joash and Njangiru, 2015). It has been established in literature that not all mergers and acquisitions resulted in improvement of the fortunes of the acquirer and make them better.

Mergers and acquisitions in Ghana have been a normal phenomenon in most industries involving both private sector business and public sector business (Oduro and Agyei, 2013). The earliest form of mergers and acquisition were driven by government's privatization agenda, which saw most state-owned enterprises taken over or sold to private entities. In the last two decades, businesses in the private sector have also engaged in some form of mergers and acquisitions. In the telecommunication sector, Vodafone acquired Ghana Telecom, Airtel acquired Zain, MTN acquired Areeba and recently the merger between Airtel and Tigo to form AirteltIGO. In the insurance industry, Provident insurance acquired old mutual, Prudential Plc acquired Express Life etc. In the food and beverage industry, there is the merger and acquisition between Fan Milk International and Abaraaj Food Industries. In the pharmaceutical industry, Dannex pharmaceutical company acquired Starwin Products and Aryton Drugs manufacturing Limited.

The highest number of mergers and acquisition in Ghana perhaps can be found in the banking industry (Barnor and Adu-Twumwaah, 2015; Yeboah et al., 2015). Studies shows that a significant part of these mergers and acquisitions in the Ghanaian banking sector were driven largely on account of recapitalization where the Bank of Ghana asked Commercial banks to increase their capital to a certain threshold (Amewu, 2014; Salami, 2015). However, some mergers and acquisitions were not directly linked to the recapitalization program as they already had the needed capital. The first of such mergers and acquisition was Societe Generale's acquisition of Social Security Bank in 1994 (Salami, 2015). Since then a number of acquisitions have taken place including, but not limited to Ecobank Ghana acquiring The Trust Bank, Fortiz private equity's acquisition of Merchant Bank Ghana, Access Bank acquired Intercontinental Bank Ghana, Capital Bank and UT bank were absorbed or acquired by GCB Bank, Fidelity Bank acquired Procredit, Bank of Africa acquired Amalgamated Bank Ghana Limited etc. What is not clear is whether all of these acquisitions have resulted in improvement in the performance of the acquired banks. What is clear, however, is that some acquisitions have increased the market share and power for some acquirers. A good example in this case is Ecobank Ghana, which became the largest bank after it completed the acquisition of The Trust Bank, a position which was held by GCB Bank. Some other leading banks in the country have also used mergers and to gain market control and boost their position in the industry ranking. Apart from Ecobank Ghana that moved up the ranking in terms of size after it acquired The Trust Bank, Fidelity Bank Ghana also moved up the ladder from second tier bank based on Price Water House Coopers banking classification to first tier.

The goal of most mergers and acquisition is to improve performance, reduce risk, tax considerations, synergies, improve economies of scale, eliminate competitions and enhance competitive advantage (Barnor and AduTwumwaah, 2015; Harvey, 2015; Maama et al., 2017). The ownership and capital structure of most banks have changed drastically as a result of mergers and acquisitions in recent times (Barnor and Adu-Twumwaah, 2015). From the policy point of view, the focus of policy makers is usually how mergers and acquisitions in the banking sector can affect the conduct of monetary policy (Maama et al., 2017). Studies have shown that increase in banking concentration results is an increase in the interest rate on loans, which improves the performance of banks in such 
markets (Moctar and Xiaofang, 2014). The increasing cases of mergers and acquisitions, especially in the Ghanaian banking sector have also resulted in more academic literature on how these acquisitions and mergers are affecting various aspects of the acquirer-being its performance, market share, service quality, employee welfare etc (Barnor and Adu-Twumwaah, 2015; Harvey, 2015; Salami, 2015; Maama et al., 2017). Even though a significant number of studies have examined the effect of mergers and acquisitions in the banking sector in Ghana and its impact on performance, the findings from these studies are inconclusive or somehow contradictory. Whereas, some of them found a positive relationship between mergers and acquisition and firm performance both in Ghana and other parts of the World (Gatsi and Agbenu, 2006; Moctar and Xiaofang, 2014; Aggarwal and Singh, 2015; Barnor and AduTwumwaah, 2015; Salami, 2015; Yeboah et al., 2015; Maama et al., 2017) others reported a negative association between mergers and acquisition and firm performance (Beena, 2006; Oduro and Agyei, 2013; Akhtar and Iqbal, 2014). Also, some of the studies were conducted in other sectors while the few on banks in Ghana used case study approach, which limits the generalization of their findings. This study therefore addresses these discrepancies in literature by using a larger sample of banks to study the effect of mergers and acquisitions on performance. The study makes significant contributions to literature. as it extends previous studies on the subject in the Ghanaian banking industry by examining the cause of mergers and acquisition as well as the processes adopted in these mergers and acquisitions in the banking industry in Ghana. The results therefore provide a much robust evidence on the consequence of mergers and acquisitions in the banking sector in Ghana. The results will also be useful to policy makers like the Bank of Ghana who has advocated for banks to merge and consolidate to become big enough to help reduce risk and improve their performance, and help clear doubts as to whether this policy direction is having positive impact on commercial banks that have merged or consolidated in Ghana in the last decade. The results will also be useful to government of Ghana in terms of regulating mergers and acquisitions in the Ghanaian banking sector. In terms of practice, the findings will assist commercial banks in Ghana to decide whether to use mergers and acquisition as a corporate strategy for growth or they should rely on natural growth.

\section{Literature Review}

\subsection{The Concept of Mergers and Acquisition}

Moctar and Xiaofang (2014) argue that mergers and acquisitions, especially in the financial sector is one of the features of globalization. This was accompanied by financial sector deregulations in developed countries like Europe before developing countries in Africa followed same. Technological innovation, and in the case of Europe the creation of single currency and the European Monetary Union were significant drivers for mergers and acquisitions (Amihud et al., 2002; Altunbaş and Marqués-Ibanez, 2008). It has been argued that the term mergers and acquisitions have mostly been used interchangeably in literature even though in reality there is some difference between the two concepts (Moctar and Xiaofang, 2014; Maama et al., 2017). Harvey (2015) defined a merger as a business combination involving two or more independent firms on almost similar terms under a joint ownership of the former two owners. Moctar and Xiaofang (2014) define a merger as simply the combination of two or more firms into one bigger organization. Oduro and Agyei (2013) in their study defined mergers as an arrangement where the assets of two separate entities come under the control of one, which still have all or substantially all the shareholders of the previous companies. Gaughan (2002) see a merger as a business combination in which only one entity survives even though two entities will have pooled resources together. Similarly, Gupta (2012) also sees merger as an amalgamation of two firms where only one firm survives and the new firm assumes the assets and liabilities of the old firms.

On the other hand, Moctar and Xiaofang (2014) defines acquisition as the purchase of one firm by another firm. They argue that the action of the purchase could be hostile or friendly as the case maybe but the significant part is that the acquirer takes control of the acquiree. Selvam et al. (2009) holds a similar view as they see acquisition as simply the purchase of an entity by another entity and assuming all or a substantial part of the assets and liabilities of the acquitted entity. Harvey (2015) defined acquisition as a situation where one entity buys all the shares or substantially all the shares in another company with ownership of the company vested in the acquirer company. The study further argues that whether a business combination is a merger or an acquisition, the outcome of the process is that only one firm survives which makes the two concepts almost similar. Maama et al. (2017) posits that acquisitions are categorized as either hostile or friendly depending on the willingness of the acquiree to sell their shares or even whether the acquirer makes an offer to the target firm board before going public with the acquisition announcement. A number of companies have been acquired against the will of the original owners, which could be described as hostile takeover. A good example in Ghana is the acquisition of HFC bank by Republic bank where Republic bank made an offer to two of the majority shareholders of HFC Bank and acquired their shares to gain significant control against the will of the original owners of HFC Bank.

Mergers and acquisitions can be classified as either vertical or horizontal and sometimes a conglomerate (Gaughan, 2002; Chen and Findlay, 2003). Horizontal mergers are where the acquiring firm buys another company in the same industry and level of business activity. Chen and Findlay (2003) reports that this type of acquisition has increased rapidly in the midst of globalization, increased competition and restructuring in many industries across the globe. A lot of the acquisitions in Ghana, particularly the banking sector falls under horizontal mergers and acquisitions. Vertical mergers and acquisition on the other hand are business combinations involving companies in different level in the value chain of an industry like a client-supplier relationship. This type of merger allows the acquiring firm to reduce business risk in either supply of raw materials or distribution systems or manage costs incurred in these services, thereby maximize profits (Chen and Findlay, 2003). The best example of this type of merger is the acquisition of Benso Oil Palm Plantation by Unilever Ghana who uses the products from Benso as raw material in its production process. A conglomerate in the context of mergers and acquisition is a business combination involving unrelated businesses in terms of activity or industry of operations. These mergers and acquisition could also be domestic or even cross-border events. A number of acquisitions and mergers in Ghana are foreign companies or even banks acquiring local ones and assuming their assets and liabilities. 


\subsection{Empirical Review}

Harvey (2015) examined the impact of mergers and acquisition on the performance of the acquiring firm using t-test analysis. The study used the merger between Mobil Oil Ghana Limited and Total Petroleum Ghana Limited. The main source of data for the study is secondary data. The results of the study revealed that the main reason for the acquisition was not profit maximizing but growth and shareholder value maximizing.

Agbloyor et al. (2012) examined the influence of financial markets on cross border mergers and acquisition in Africa. The study used secondary data from 14 African countries ranging from 1993 to 2008. The study used panel data relying on feasible generalized least square for data analysis. The results of their study revealed that banking sector development promotes cross border mergers and acquisition. Even though the study did not find string evidence relating Stock market development to cross border mergers and acquisition it found that cross border mergers and acquisition promotes financial and stock market development in Africa.

Maama et al. (2017) in their study examined the impact of business combination or consolidation on the financial performance of commercial banks in Ghana. The study used a sample of two banks; Ecobank Ghana Limited and Access Bank Ghana Limited. The study relied on secondary data from the financial statement of these banks using descriptive statistics and correlation as well as regression as statistical tool for analysis. The sample period covered the year 2009 to 2011 as pre-merger period and 2012 to 2015 as post-merger period. Net profit margin and return on capital employed were the two variables that were used to represent firm performance. The results of the study revealed that mergers and acquisition led to more than $80 \%$ increase in net assets immediately after the acquisition. The results showed that there is growth in profit after the merger but at a decreasing rate. The regression results showed that mergers and acquisition had positive impact on the performance of the two banks. Oduro and Agyei (2013) examined the effect of mergers and acquisition on firm performance of listed firms in Ghana. The study used a sample of five companies with data covering the period from 1999 to 2010 . The results showed significant difference in profitability before and after the mergers and acquisition and showed evidence of decreasing profit after the merger and acquisition. The study established a negative and statistically significant association between mergers and acquisition and performance of listed firms in Ghana.

Yeboah et al. (2015) examined the effect of mergers and acquisition on service quality using Ecobank and Access Bank as case studies. The study used primary data from questionnaire and showed that mergers and acquisition had significant positive impact on service quality in the banking industry.

Barnor and Adu-Twumwaah (2015) explored the performance of commercial banks after mergers and acquisition. The study used data from Ecobank Ghana and UT Financial services as case studies to examine the valuation methods adopted by the acquiring companies and how that affected the post-acquisition performance of the companies. The study found that firms that adopted a good valuation strategy and used the best available financing strategy for the merger and acquisition improved their corporate value and financial performance after the acquisition.

Moctar and Xiaofang (2014) examined the effect of mergers and acquisition on performance of West African Banks. Using secondary data their study measured performance using liquidity ratios, and profitability ratios in the form of return on assets and return on equity whiles including one investment ration such as earnings per share. The study used a sample of four selected from Ghana, Nigeria and Niger. The analysis showed that the liquidity of the banks improved both in the short term and long term after the mergers and acquisition. Also, the profitability ratios and the investment ratio decreased in the early years of the mergers and acquisition but increased three years later. The study therefore concluded that mergers and acquisition has negative effect on performance in the short terms but positive effect in the long term.

Abdul-Ramon and Ayorinde (2012) in their study examined the impact of mergers and acquisition on selected banks in Nigeria. Their analysis of performance focused on gross margin, profit after tax and deposit profile or growth. The study purposively selected seven banks in Nigeria for the study. The results of the analysis showed that there was significant improvement in performance of the banks in the post-merger period. The study did not use any complex statistical analysis but only relied on trend in profit growth and deposit growth. The major limitation of such analysis is that it failed to account for inflation and time value of money. It also did not examine profitability in relation to size by using return on assets and return on capital employed.

Koi-Akrofi (2014) examined the motives for mergers and acquisitions in Ghana using a sample of firms in the telecommunication industry. The study relied on secondary data from literature and reports on mergers and acquisitions in the telecommunication sector in Ghana. The results of the study showed that the major motives of mergers and acquisition in Ghana's telecom sector are synergy, growth, improving market share and market competitiveness, creating wealth to shareholders and empire building for managers.

Adoma (2016) examined the impact of mergers and acquisition on firm performance in Ghana using Guinness Brewery Ghana Limited as a case study. The study relied on both primary and secondary data to achieve the objectives of the study. The secondary data involved financial information for 2 years prior to the acquisition and five years after the acquisition. The study revealed that there was a consistent improvement in the financial performance of the company after the merger and acquisition. The key contributing factors for this improved financial performance were supply of raw materials, innovative marketing, employee commitment etc. They also reported that the merger process faced challenges in the area of the cost of the business combination, source of finance, regulatory compliance, integration of information technology systems among others.

Altunbaş and Marqués-Ibanez (2008) examined the effect of mergers and acquisition on bank performance in Europe. The study relied mostly on secondary data on selected banks from different European countries and reported that banks merger and acquisition in Europe resulted in improvement in return on capital. There was however a significant difference in performance for domestic mergers and cross border mergers. There was also evidence of integration challenges in the post-merger period in terms of costs and well as technological structures.

Joash and Njangiru (2015) examined the impact of mergers and acquisition on financial performance of commercial banks in Kenya. The study was conducted on merger and acquisition that have taken place in the Kenyan banking sector between the period of 2000 and 2014 with a sample of 14 banks, which had all gone through mergers and acquisition. The results of the study showed that mergers and acquisition improved shareholder value 
of the banks involved. The study also revealed that the driving motive behind most if the mergers and acquisition in Kenya banking sector was to improve profitability.

Amewu (2014) studied the impact of mergers and acquisition on stock return before and during the financial crisis between 2006 and 2009. The study used secondary data collected from international websites such as Reuters, Bloomberg, etc. and reported a significant impact of mergers and acquisition announcement on share prices during the period or even before the period.

Akinbuli and Kelilume (2013) examined the effect of mergers and acquisition on growth, profitability and efficiency of corporations in Nigeria. The study used a survey of the financial sector in Nigeria. The results showed that mergers and acquisition does not solve financial distress of companies. However, the study found that mergers and acquisition influenced profitability and growth in Nigeria. On the other hand, operational efficiency suffers in the short run before normalizing subsequently in the long run.

Salami (2015) examined the impact of mergers and acquisition on the banking industry in Ghana using Societe Generale as the case study. The study relied on a mixed approach using data from both primary and secondary sources. Their results showed some improvement in financial performance of the bank after the acquisition. However, the results could not find any evidence of cost reduction in the post-acquisition period.

\section{Methodology}

The study relied on secondary data collected from the financial statement of commercial banks that have undergone mergers and acquisitions over the last ten years. Data from the Price Water House Coopers Annual Banking Survey also served as another source of evidence, especially for the years that the study could not get the annual report for the respective banks. The sample frame includes GCB Bank, Ecobank Ghana Limited, Fidelity Bank Ghana Limited, Access Bank Limited, Bank of Africa and Universal Merchant Bank. The study period covered both pre-acquisition period and post-acquisition period. The study, however, excluded Societe Generale Ghana because of lack of data for the bank prior to the acquisition. It also excluded new mergers and acquisition such as the Absa Group acquisition of Barclays Bank Ghana Limited as well as First Atlantic bank because financial data for the pre and post-acquisition period were not available for these mergers and acquisitions.

The empirical model developed for the study is similar to those used in previous studies to examine the effect of mergers and acquisition on bank performance in Ghana (Oduro and Agyei, 2013; Maama et al., 2017). The study used three empirical models which involves the use of three different measures of performance. The measures of bank performance used in the study include Net profit Margin (NPM), Return on Assets (ROA) and Return on Equity (ROE). The empirical models are presented below;

$$
\begin{aligned}
& N P M_{i t}=\beta_{0}+\beta_{1} M A_{i t} \beta_{2} S I Z E_{i t}+\beta_{3} O W N_{i t}+\varepsilon_{i t} \\
& R O A_{i t}=\beta_{0}+\beta_{1} M A_{i t} \beta_{2} S I Z E_{i t}+\beta_{3} O W N_{i t}+\varepsilon_{i t} \\
& R O E_{i t}=\beta_{0}+\beta_{1} M A_{i t} \beta_{2} S I Z E_{i t}+\beta_{3} O W N_{i t}+\varepsilon_{i t}
\end{aligned}
$$

Table-1. Dependent and independent variables and their measurement.

\begin{tabular}{l|l|l} 
Where \\
\hline Variable & Meaning & Measurement \\
\hline NPM & Net Profit Margin & Profit after tax divided by interest income multiplied by 100 \\
\hline ROA & Return on Assets & Profit before tax divided by total assets multiplied by 100 \\
\hline ROE & Return on Equity & Profit after tax divided by total Equity multiplied by 100 \\
\hline MA & Mergers and Acquisition & Dummy, 1 for post-acquisition and o for pre-acquisition period \\
\hline SIZE & Firm size & Natural logarithm of Total Assets \\
\hline OWN & Foreign ownership & Dummy, 1 if bank is a foreign bank, o otherwise. \\
\hline
\end{tabular}

\subsection{Dependent and Independent Variables}

The study has three dependent variables, which were used to measure bank performance. These are net profit margin, return on assets and return on equity. Return on assets and return equity are the two most popular performance ratios used in most studies (Moctar and Xiaofang, 2014; Barnor and Adu-Twumwaah, 2015; Salami, 2015).

The independent variables in this study are mergers and acquisition (MA) which is measured as a dummy variable in line with previous studies (Moctar and Xiaofang, 2014; Barnor and Adu-Twumwaah, 2015; Salami, 2015; Maama et al., 2017).

\subsection{Control Variables}

Control variable are other independent variables that can predict firm performance but are not the variable of interest for the study. The first control variable is firm size. Researchers established that the size of commercial banks in Ghana influence firm performance (Maama et al., 2017; Musah, 2017). These studies argue that bigger banks enjoy economies of scale and are able to undertake bigger transactions, which have lower risk and improve their performance.

The second control variable is the age of the bank, which have also been cited as potential determinant of bank performance in Ghana (Maama et al., 2017). Banks that have operated for a long time in Ghana understand the industry-the risk profile of their clients and the macroeconomic environment, and are able to take steps that will improve their financial performance. The last control variable is foreign ownership, which have also been found to be a potential determinant of bank performance in Ghana (Musah, 2017). 


\begin{tabular}{l|c|c|c|c}
\hline \multicolumn{5}{c}{ Table-2. Descriptive statistics. } \\
\hline Variables & Mean & Std. Dev. & Min & Max \\
\hline Net Profit Margin (NPM) & 0.2091 & 0.1822 & -0.346 & 0.641 \\
\hline Return on Assets (ROA) & 0.0411 & 0.0752 & 0.073 & 0.372 \\
\hline Return on Equity (ROE) & 0.1481 & 0.2453 & -1.095 & 0.664 \\
\hline Mergers \& Acquisition (MA) & 0.575 & 0.4975 & 0 & 1 \\
\hline Firm Size (SIZE) & 9.1578 & 0.4519 & 8.274 & 10.03 \\
\hline Foreign Ownership (OWN) & 0.4875 & 0.5029 & 0 & 1 \\
\hline
\end{tabular}

The results from Table 2 above shows that on average the sampled banks are able to keep $21 \%$ of their interest income as profit after taking care of all major business operating expenses. Majority of studies that examined the effect of mergers and acquisition on bank performance did have net profit margin as one of its variable. However, the $20 \%$ net profit margin appears very impressive given the competitive nature of the banking industry. The $20 \%$ net profit margin is higher than the result of Harvey (2015) whose study reported a net profit margin average of $3 \%$.

The second variable (return on assets) showed a mean of about $4 \%$ over the study period with a minimum of negative 0.07 and maximum of 0.372 . The results suggest that the banks sampled were only able to manage $4 \%$ returns on their entire assets over the study period. This figure is lower than the return of assets of $12 \%$ reported by Harvey (2015) in mergers and acquisition and profitability based on Total Petroleum Ghana.

The return on equity revealed a mean score of $14.81 \%$ over the study period, suggesting that the sampled commercial banks are able to generate $14.81 \%$ returns on shareholders' investments. The rate is however lower compared to that of the findings of Oduro and Agyei (2013) whose study reported a return on equity of $22 \%$ based on a sample of listed financial and non-financial firms on the Ghana Stock Exchange. Harvey (2015) also reported a much higher return on equity of $33 \%$ even though that study was not based on commercial banks in Ghana.

On the mergers and acquisition variable, the results suggest that $57.5 \%$ of the sample observation fall under the post-merger and acquisition period including the merger year itself. This is slightly higher that the findings of Oduro and Agyei (2013) who reported 51\% as their mean score for mergers and acquisition using the same measurement approach.

Size of the banks which is measured as the natural logarithm of total assets ranges from 8.24 to 10.03 with a mean score of 9.15. This is similar to the findings of Oduro and Agyei (2013)who also reported a mean for natural logarithm of total assets of 8.27 and a maximum of 10.16 .

Table 2 shows that $49 \%$ of the banks sampled were foreign banks and the rest local banks based on the sample observations. This is because majority of the mergers and acquisitions were in the form of foreign banks acquiring local banks.

\subsection{Correlation Analysis between Net Profit Margin and Independent Variable}

Table 3 shows the results of a correlation matrix of the relationship between mergers and acquisition and net profit margin.

Table-3. Correlation results for NPM and other variables.

\begin{tabular}{c|c|c|c|c}
\hline Variables & NPM & MA & SIZE & OWN \\
\hline NPM & 1.000 & & & \\
\hline MA & -0.1368 & 1.000 & & \\
\hline SIZE & $0.2265^{*}$ & $0.3081^{* * *}$ & 1.000 & 1.000 \\
\hline OWN & 0.0986 & $0.6361^{* * *}$ & 0.0709 & significance level and * means significant at
\end{tabular}

$10 \%$ significance level).

The results from Table 3 above shows that there is a negative correlation between net profit margin and mergers and acquisition. The result however is statistically insignificant but can be interpreted to mean that mergers and acquisition reduces the net profit margins of commercial banks in Ghana. The result is partly consistent with the findings of Oduro and Agyei (2013)who also reported a negative correlation between mergers and acquisition of bank performance.

The results show a positive correlation between mergers and acquisition and net profit margin. The result is also statistically significant at $10 \%$ significance level. The results suggest that larger banks are able to maintain high net profit margin and as such are more cost-efficient compared to smaller banks. Foreign ownership showed a positive correlation with net profit margin but statistically insignificant.

\subsection{Correlation Analysis between Return of Assets and Independent Variable}

Table-4. Correlation between mergers and acquisition and return on assets.

\begin{tabular}{c|c|c|c|c}
\hline Variable & ROA & MA & SIZE & OWN \\
\hline ROA & 1.000 & & & \\
\hline MA & 0.1568 & 1.000 & & \\
\hline SIZE & $0.5109^{* * *}$ & $0.3081^{* * *}$ & 1.000 & \\
\hline OWN & 0.0777 & $0.6361^{* * *}$ & 0.0709 & 1.000 \\
\hline
\end{tabular}

Note: *** means significant at $1 \%$ significance level, ** means significant at $5 \%$ significance level and $*$ means significant at $10 \%$ significance level).

The result of the correlation analysis from Table 4 above shows a positive correlation between mergers and acquisition and return on assets. The result however is statistically insignificant and also shows a weak correlation 
between the two variables, suggesting that mergers and acquisition translates into improvement in return on assets even though such improvement is statistically insignificant.

Bank size exhibited a positive correlation with return on assets and the result is also statistically significant. Similarly, foreign ownership showed a positive correlation with return on assets, but statistically insignificant.

\subsection{Correlation Analysis between Return of Equity and Independent Variable} below.

The results of the correlation between mergers and acquisition and return on equity are presented in Table 5

Table-5. Correlation Results for ROE and other independent variables.

\begin{tabular}{c|c|c|c|c}
\hline Variable & ROE & MA & SIZE & OWN \\
\hline ROE & 1.000 & & & \\
\hline MA & 0.0014 & 1.000 & & \\
\hline SIZE & $0.3868^{* * *}$ & $0.3081^{* * *}$ & 1.000 & \\
\hline OWN & 0.0053 & $0.6361^{* * *}$ & 0.0709 & 1.000 \\
\hline
\end{tabular}

Note: **** means significant at $1 \%$ significance level, ** means significant at $5 \%$ significance level and $*$ means significant at $10 \%$ significance level).

The correlation result shows a positive and weak correlation between mergers and acquisition and return on equity. The result is also statistically insignificant. This is inconsistent with the findings of Oduro and Agyei (2013) who reported a negative and significant association between mergers and acquisition and return on equity of listed firms in Ghana.

The correlation analysis presented for the three dependent variables shows conflicting results. Whiles the first analysis showed that mergers and acquisition reduces net profit margin, the subsequent analysis did not find evidence of negative correlation. Moreover, the correlation coefficients among the independent variables are all less than 0.8 , suggesting that there is no evidence of multicollineraity. Overall, the correlation analysis presents inconclusive results on the effect of mergers and acquisition on bank performance in Ghana.

\subsection{Effect of Mergers and Acquisition on Net Profit Margin}

Table 6 shows the effect of mergers and acquisition on the net profit margin of the banks. The regression results showed an Adjusted R-squared of 18\% suggesting that the independent variable can only explain $18 \%$ of the variations in the dependent variable. The probability of the F-statistics is however significant at $10 \%$ significance level suggesting that to some extent the model is well fit.

Table-6. Regression results on the effect of mergers and acquisition on NPM.

\begin{tabular}{l|c|c|c}
\hline Variable & Coefficient & Std.Err & $\mathbf{Z}$ \\
\hline MA & $-0.1488^{*} *$ & 0.0598 & -2.49 \\
\hline SIZE & $0.1065^{*} *$ & 0.0535 & 1.99 \\
\hline OWN & 0.0816 & 0.0602 & 1.36 \\
\hline CONT & -0.7251 & 0.481 & -1.51 \\
\hline Overall R-squared & 0.1795 & & \\
\hline Wald Chi2 (3) & 7.01 & & \\
\hline Probability>Chi2 & 0.07 & & \\
\hline $\begin{array}{l}\text { Note: *** means significant at } 1 \% \text { significance level, ** means significant at 5\% significance level and * means } \\
\text { significant at } 10 \% \text { significance level) }\end{array}$
\end{tabular}

significant at $10 \%$ significance level).

The results indicate that there is a statistically significant negative association between mergers and acquisition and net profit margin at 5\% significance level, suggesting that mergers and acquisition is a significant determinant of net profit margin. The results imply that mergers and acquisition reduce net profit margin of commercial banks in Ghana.

Bank size had a positive association between mergers and acquisition and net profit margin. The result is also statistically significant at 5\% significance level and shows that bigger banks have higher net profit margin. The results further show that foreign ownership does not significantly influence net profit margin of commercial banks in Ghana.

\subsection{Effect of Mergers and Acquisition on Return on Assets}

Table 7 shows the effect of mergers and acquisition on the return on assets of the banks. The overall R-squared of $24 \%$ suggest that the independent variable can explain $24 \%$ of the variation in the dependent variable. The probability of the F-statistics is also statistically significant at $1 \%$ significance level, which suggest that the model is well-fit.

Table-7. Regression results on the effect of mergers and acquisition on ROA

\begin{tabular}{|c|c|c|c|}
\hline Variable & Coefficient & Std.Err & $\mathbf{Z}$ \\
\hline MA & 0.0087 & 0.0218 & 0.4 \\
\hline SIZE & $0.0745 * * *$ & 0.0205 & 3.64 \\
\hline OWN & -0.0164 & 0.0227 & -0.72 \\
\hline CONT & -0.6391 & 0.1843 & -3.47 \\
\hline Overall R-squared & 0.2426 & & \\
\hline Wald Chi2 (3) & 18.84 & & \\
\hline Probability $>$ Chi 2 & 0.0003 & & \\
\hline
\end{tabular}

significant at $10 \%$ significance level). 
The results show that there is a positive relationship between mergers and acquisition and return on assets. The result is however statistically insignificant which suggest that mergers and acquisition is not a significant determinant of return on assets. Thus, even though mergers and acquisition in the banking sector improves bank performance, such improvements are statistically insignificant.

The results also show a positive and statistically significant association between bank size and return on assets, implying that larger banks are able to take on bigger risk of finance that allows them to maximize profit. Furthermore, larger banks also enjoy economics of scale, which help to improve their profitability. The last control variable foreign ownership showed a positive association but statistically significant.

\subsection{Effect of Mergers and Acquisition on Return on Equity}

Previous studies on mergers and acquisition and its effect on profitability have mostly used return on equity as a measure of performance as they focus more on the return on equity shareholder's investments. The regression analysis showed an overall Adjusted R-squared of $17 \%$, which suggest that the independent variable can only explain $17 \%$ of the variations in the dependent variable. The probability of the F-statistic is statistically significant at $5 \%$ significance level. The results of the regression analysis for this variable are presented in Table 8:

\begin{tabular}{l|c|c|c}
\multicolumn{4}{c}{ Table-8. Regression results on the effect of mergers and acquisition on ROE. } \\
\hline Variable & Coefficient & Std. Err & $\mathbf{Z}$ \\
\hline MA & -0.0898 & 0.0711 & -1.26 \\
\hline SIZE & $0.2301 * * *$ & 0.0899 & 2.84 \\
\hline OWN & 0.0423 & 0.0558 & 0.76 \\
\hline CONT & -1.9285 & 0.7521 & -2.56 \\
\hline Overall R-squared & 0.1702 & & \\
\hline Wald Chi2 (3) & 9.13 & & \\
\hline Probability>Chi2 & 0.027 & & \\
\hline $\begin{array}{l}\text { Note: *** means significant at 1\% significance level, ** means significant at 5\% significance level and * means significant } \\
\text { at 10\% significance level). }\end{array}$
\end{tabular}

The results show that there is a negative relationship between mergers and acquisition and return on equity. The result is however statistically insignificant and shows that mergers and acquisitions in the Ghanaian banking industry does not significantly influence return on equity.

Bank size is positively associated with return on equity. The result suggests that larger banks are able to generate more return to their shareholders as compared to smaller banks. Finally, foreign ownership did not have any significant association with return on equity.

\section{Discussion of Findings}

The regression analysis showed a negative association between mergers and acquisition and net profit margin. The result was also statistically significant and show mergers and acquisition have not improved bank costefficiency. The result is inconsistent with previous studies such as Harvey (2015) who reported a positive but insignificant association between mergers and acquisition and net profit margin. However, the result is similar to the findings of Salami (2015) who did not find any evidence of reduction in cost after merger and acquisition. The study result revealed that the banks' cost increased above the increase in interest income in the post-acquisition period affecting the efficiency of the bank and eventually profitability. The result is also consistent with the findings of Adu-Darko and Bruce-Twum (2014) whose study reported a downward trend in all profitability measures. The result is however inconsistent with the findings of Maama et al. (2017) who reported a positive and statistically significant relationship between mergers and acquisition and bank net profit margin. Overall, the result suggests that mergers and acquisition in the Ghanaian banking sector reduces net profit margin of the commercial banks involved.

The result of the regression analysis showed a statistically insignificant positive relationship between mergers and acquisition and return on assets, suggesting that mergers and acquisition is not a significant determinant of banks return on assets. The result contradicts the findings of Moctar and Xiaofang (2014) who reported a negative effect of mergers and acquisition in the short run but positive effect in the long run based on a sample of commercial banks in West Africa. The result is also contrary to the findings of Abdul-Ramon and Ayorinde (2012) who reported improved financial performance of commercial banks post-merger and acquisition in Nigeria. Also, the result is inconsistent with the findings of Maama et al. (2017) who reported positive impact of mergers and acquisition on bank profitability in Ghana. The result is however consistent with the findings of Akinbuli and Kelilume (2013) who reported that mergers and acquisition does not significantly influence firm performance in Nigeria. Also, Harvey (2015) reported that profitability results in the post-merger period of firms in Ghana declined suggesting that mergers and acquisition does not improve financial performance of firms in Ghana. The result is however also at variance with the findings of Adu-Darko and Bruce-Twum (2014) who reported a downward trend in profitability of firms used for their study, suggesting that mergers and acquisition does not improve firm performance.

Even though the ultimate goal of every merger and acquisition is to improve return to its shareholder or maximize shareholders value, the regression results revealed a negative association between mergers and acquisition and return on equity. This result is however not statistically significant and suggest that banks return on shareholders' investment does not increase after a merger and acquisition, which is consistent with the findings of Adu-Darko and Bruce-Twum (2014) who reported a reduction in profitability of the case company in Ghana used for their study, but inconsistent with the findings of Moctar and Xiaofang (2014) who reported that mergers and acquisition was negatively associated with bank profitability in the short run but positively associated with bank profitability in the long run. The result is also contrary to the findings of Abdul-Ramon and Ayorinde (2012) who reported improved financial performance of the companies in the post-merger and acquisition period. Furthermore, the result is at variance with the findings of Oduro and Agyei (2013) who found a negative and 
statistically significant relationship between mergers and acquisition and return on equity of listed firms on the Ghana Stock Exchange. The result is similar to the findings of Barnor and Adu-Twumwaah (2015) who reported a decrease on return on equity after the mergers and acquisition by the banks in their study. The result is partly consistent and partly inconsistent with the findings of Maama et al. (2017) where it was reported that even though there was a decline in return on capital employed by banks in the first three years after the merger and acquisition, there was a positive relationship between mergers and acquisition and bank profitability. The result contradicts the findings of Joash and Njangiru (2015) who found that mergers and acquisition in Kenyan banking sector improved shareholder value. Harvey (2015) on the other hand showed a decline in firm profitability including return on equity in the post-acquisition period, which is consistent with the findings of this study. The results also align with the findings of Adu-Darko and Bruce-Twum (2014) who found that profitability of commercial banks declined after mergers and acquisitions.

Overall, the results show inconclusive evidence on the consequence of mergers and acquisition on bank performance in Ghana. The result shows a positive and statistically significant association between bank size and bank profitability. The result is consistent with the view that larger banks are able to take on bigger risk finance that allows them to maximize profit. Furthermore, larger banks also enjoy economies of scale, which help to improve their profitability.

\section{Conclusion}

The study examined the consequence of mergers and acquisition on net profit margin, return on assets and return on equity. The results of the study with regards to the impact of mergers and acquisition on bank profitability are however inconclusive. The study showed a negative and significant association between mergers and acquisition and net profit margin and also found a positive but statistically insignificant relationship between mergers and acquisition and return on assets of commercial banks in Ghana. The study further found a negative but statistically insignificant relationship between mergers and acquisition and return on equity. The results suggest that there is no conclusive evidence of the impact of mergers and acquisition on bank performance in Ghana. The implication of the results is that mergers and acquisition might not necessarily improve bank financial performance. On the control variable, bank size showed a significant relationship with net profit margin, return on assets and return on equity. The results suggest that banks with larger sizes are able to take bigger financial transactions and reduce expenses and improve financial performance. This confirms the assertion that larger banks enjoy economies of scale and improved financial performance as compared to smaller banks. The results suggest increase cost of operations in the post-merger period as evidenced in the negative association between mergers and acquisition and net profit margin. The study therefore recommends that companies should adopt a comprehensive strategy to reduce cost in the post-merger and acquisition period in order to maximize profitability. The study further recommends that future research expand to include other aspects of bank performance like liquidity, assets quality in terms of how mergers and acquisition affect these performance indicators.

\section{References}

Abdul-Ramon, O.A. and A.O. Ayorinde, 2012. Effects of merger and acquisition on the performance of selected commercial banks in Nigeria. International Journal of Business and Social Research, 2(7): 148-157.

Adoma, A., 2016. Assessing the effects of mergers and acquisitions on the performance of a company: A Case Study of Guinness Ghana Breweries Limited (Doctoral Dissertation).

Adu-Darko, E. and E. Bruce-Twum, 2014. The pre and post Merger performance of firms in Ghana: The experience of Guinness Ghana Breweries Limited. Journal of Finance and Accounting, 2(1): 8-18.

Agbloyor, E.K., J. Abor, C.K. Adjasi and A. Yawson, 2012. Domestic banking sector development and cross border mergers and acquisitions in Africa. Review of Development Finance, 2(1): 32-42.Available at: https://doi.org/10.1016/j.rdf.2012.01.003.

Aggarwal, M. and S. Singh, 2015. Effect of merger on financial performance: A case study of Kingfisher Airlines.

Akhtar, S. and J. Iqbal, 2014. An empirical analysis of pre and post merger or acquisition impact on financial performance: A case study of Pakistan telecommunication limited. European Journal of Accounting Auditing and Finance Research, 3(1): 69-80.

Akinbuli, S.F. and I. Kelilume, 2013. The effects of mergers and acquisition on corporate growth and profitability: Evidence from Nigeria. Global Journal of Business Research, 7(1): 43-58.

Altunbaş, Y. and D. Marqués-Ibanez, 2008. Mergers and acquisitions and bank performance in Europe: The role of strategic similarities. Journal of Economics and Business, 60(3): 204-222.Available at: https://doi.org/10.1016/j.jeconbus.2007.02.003.

Amewu, G., 2014. Implication of mergers and acquisitions on stock returns before and during the 2007-2009 credit crunch: An event study. African Review of Economics and Finance, 6(1): 102-119.

Amihud, Y., G.L. DeLong and A. Saunders, 2002. The effects of cross-border bank mergers on bank risk and value. Journal of International Money and Finance, $21(6):$ 857-877.Available at: https://doi.org/10.1016/s0261-5606(02)00026-8.

Barnor, C. and D. Adu-Twumwaah, 2015. Bank performance, mergers and acquisitions in Ghana: The case of Ecobank Ghana-TTB Takeover and UT financial services-BPI Merger. International Journal of Sciences: Basic and Applied Research, 24(6): 77-91.

Beena, S., 2006. Mergers and acquisitions in the Indian pharmaceutical industry: Nature, structure and performance.

Chen, C. and C. Findlay, 2003. A review of cross-border mergers and acquisitions in APEC. Asian-Pacific Economic Literature, 17(2): 14-38.

Cho, S.Y., J.D. Arthurs, D.M. Townsend, D.R. Miller and J.Q. Barden, 2016. Performance deviations and acquisition premiums: The impact of CEO celebrity on managerial risk-taking. Strategic Management Journal, 37(13): 2677-2694.Available at: https://doi.org/10.1002/smj.2468.

Gatsi, J.G. and D. Agbenu, 2006. A case of Cross-Boarder merger and acquisition in Ghana. Center for Finance, School of Business, Economics and law, Goteborg University.

Gaughan, P.A., 2002. Mergers, acquisitions and corporate restructurings. 3rd Edn., New York: John Wiley \& Son.

Gupta, P.K., 2012. Mergers and acquisitions (M\&A): The strategic concepts for the nuptials of corporate sector. Innovative Journal of Business and Management, 1(4): 60-68.

Haleblian, J. and S. Finkelstein, 1999. The influence of organizational acquisition experience on acquisition performance: A behavioral learning perspective. Administrative Science Quarterly, 44(1): 29-56.Available at: https://doi.org/10.2307/2667030.

Harvey, S.K., 2015. The role of mergers and acquisitions in firm performance: A Ghanaian case study. Journal of Applied Business \& Economics, 17(1): 66-77

Joash, G.O. and M.J. Njangiru, 2015. The effect of mergers and acquisitions on financial performance of banks (a survey of commercial banks in Kenya). International Journal of Innovative Research and Development, 4(8): 101-113.

Koi-Akrofi, G.Y., 2014. Motives for telecom mergers and acquisitions. International Journal of Innovation and Applied Studies, 9(4): 18091817 .

Maama, H., J. Poku and K. Frimpong, 2017. Business consolidation and its impact on financial performance: Evidence from The Ghanaian banking industry. European Journal of Accounting Auditing and Finance Research, 5(8): 62-76. 
Mensah, E. and J.M. Onumah, 2017. Mergers and acquisitions in the Era of globalizatıon: The Ghanaian experience. Journal of Accounting and Finance, 17(3): 96-114.

Moctar, N.B. and C. Xiaofang, 2014. The impact of mergers and acquisition on the financial performance of West African Banks: A case study of some selected commercial banks. International Journal of Education and Research, 2(1): 1-10.

Musah, A., 2017. The impact of capital structure on profitability of commercial banks in Ghana. Asian Journal of Economic Modelling, 6(1): 21-36.Available at: ttps://doi.org/10.18488/journal.8.2018.61.21.36

Oduro, M., I. and S.K. Agyei, 2013. Mergers \& acquisition and firm performance: Evidence from the Ghana stock exchange. Research Journal of Finance and Accounting, 4(7): 99-108.

Saboo, A.R., A. Sharma, A. Chakravarty and V. Kumar, 2017. Influencing acquisition performance in high-technology industries: The role of innovation and relational overlap. Journal of Marketing Research, 54(2): 219-238.Available at: https://doi.org/10.1509/jmr.15.0556.

Salami, K., 2015. Impact of mergers and acquisition (MA) on performance of Ghana's banking industry. Standard Research Journal of Business Management, 3(4): 072 -079.

Seidu, S.S.B., 2009. The impact of mergers and acquisitions on the corporate financial performance of Guinness Ghana Breweries Limited. Cape Coast: University of Cape Coast.

Selvam, M., M. Babu, G. Indhumathi and B. Ebenezer, 2009. Impact of mergers on the corporate performance of acquirer and target companies in India. Journal of Modern Accounting and Auditing, 5(11): 235-251.

Yeboah, J., E.K. Asirifi and S. Ampadu, 2015. The impact of mergers and acquisitions on service quality of banks in Ghana: Case study of Ecobank and Access Bank Ghana. International Journal of Business and Management, 10(12): 167-180.Available at: https://doi.org/10.5539/ijbm.v10n12p167.

Zaremba, A. and M. Płotnicki, 2016. Mergers and acquisitions: Evidence on post-announcement performance from CEE stock markets. Journal of Business Economics and Management, 17(2): 251-266. 